Int. J. Electrochem. Sci., 13 (2018) 12391 - 12403

International Journal of

ELECTROCHEMICAL

SCIENCE

www.electrochemsci.org

\title{
Electrochemical Degradation of Acetaminophen in the Absence/Presence of Ce(IV)
}

\author{
Kuo-Lin Huang * , Tzu-Ying Tang \\ Department of Environmental Science and Engineering, National Pingtung University of Science and \\ Technology, Pingtung 91201, Taiwan (ROC) \\ *E-mail: huangkl@mail.npust.edu.tw
}

doi: $10.20964 / 2018.12 .139$

Received: 29 September 2018 / Accepted: 25 October 2018 / Published: 5 November 2018

This study investigates the degradation of acetaminophen (AP) using Ce(IV) oxidation with/without the aid of electrolysis on a Ti/ $\mathrm{PbO}_{2}$ anode in $\mathrm{Na}_{2} \mathrm{SO}_{4}+\mathrm{H}_{2} \mathrm{SO}_{4}$ solutions under different operating conditions. The results show that $p$-benzoquinone $(p-\mathrm{BQ})$ is an intermediate generated from AP dergadation. Increases in temperature $\left(25-80^{\circ} \mathrm{C}\right)$ did not accelerate the degradation of AP but increased the rate of $p$ BQ degradation. The AP degradation efficiencies all achieved $100 \%$ within 2 min despite the difference in $\mathrm{Ce}(\mathrm{IV})$ concentration $(100-4000 \mathrm{ppm})$ and initial AP concentration ( $\left.\mathrm{AP}_{\mathrm{o}}=10-100 \mathrm{ppm}\right)$. The $p$-BQ degradation was noticeably quicker at higher $\mathrm{Ce}(\mathrm{IV})$ concentrations than at lower ones at $\mathrm{AP}_{\mathrm{o}}=10 \mathrm{ppm}$, while the optimal $\mathrm{Ce}$ (IV) concentration range was 375-500 ppm, which showed better $p$-BQ degradation rates than the other $\mathrm{Ce}(\mathrm{IV})$ concentrations at $\mathrm{AP}_{\mathrm{o}}=100 \mathrm{ppm}$. At $\mathrm{AP}_{\mathrm{o}}=10 \mathrm{mg} / \mathrm{L}$, the increase in the current density without the addition of $\mathrm{Ce}(\mathrm{IV})$ increased the rate of $\mathrm{AP}$ degradation (pseudo-first-order rate constant $\left.(k)=1.55 \times 10^{-3}-6.04 \times 10^{-3} \mathrm{~s}^{-1}\right)$ and $p$-BQ formation/degradation at $0.5-1.5 \mathrm{~A} / \mathrm{cm}^{2}$ and $25^{\circ} \mathrm{C}$, but the electrochemical degradation efficiency of AP decreased with an increase in temperature (20$\left.80^{\circ} \mathrm{C}\right)\left(k=1.55 \times 10^{-3}-3.58 \times 10^{-4} \mathrm{~s}^{-1}\right)$. The AP degradation efficiency was lower using electrolysis alone at $0.5-1.5 \mathrm{~A} / \mathrm{cm}^{2}$ and $20-80^{\circ} \mathrm{C}$ than when using only $\mathrm{Ce}(\mathrm{IV})$ oxidation at $80^{\circ} \mathrm{C}$. Compared with the $\mathrm{Ce}(\mathrm{IV})$ oxidation method (without electrolysis), the electrochemical plus $\mathrm{Ce}(\mathrm{IV})$-mediated (E+Ce(IV)) process achieved faster $p$-BQ degradation at lower temperatures. This $\mathrm{E}+\mathrm{Ce}(\mathrm{IV})$ process was also more efficient for $\mathrm{AP}$ degradation and $p$-BQ formation/degradation than electrolysis alone. At $\mathrm{AP}_{\mathrm{o}}=100 \mathrm{ppm}, 25^{\circ} \mathrm{C}$, and $0.5 \mathrm{~A} / \mathrm{cm}^{2}$, the TOC removal $\left(k=8.83 \times 10^{-5}-1.65 \times 10^{-4} \mathrm{~s}^{-1}\right)$ increased with increases in Ce(IV) concentrations (200-375 ppm) using the E+Ce(IV) process for AP degradation. For AP and $p$-BQ degradation, the $\mathrm{Ce}(\mathrm{IV})$ electrochemically regenerated from a spent $\mathrm{Cr}$-etching solution was as good as the purchased one.

Keywords: degradation; acetaminophen (AP); $p$-benzoquinone (p-BQ); $\mathrm{Ce}(\mathrm{IV}) ; \mathrm{PbO}_{2}$ electrode

\section{$\underline{\text { FULL TEXT }}$}


(C) 2018 The Authors. Published by ESG (www.electrochemsci.org). This article is an open access article distributed under the terms and conditions of the Creative Commons Attribution license (http://creativecommons.org/licenses/by/4.0/). 